\title{
The Importance of Composition of Fiscal Policy: Evidence from Different Exchange Rate Regimes*
}

\author{
Philip R. Lane \\ Trinity College Dublin \\ and CEPR
}

\author{
Roberto Perotti \\ European University Institute \\ and CEPR
}

October 25, 2001

\begin{abstract}
We study the macroeconomic effects of fiscal policies in an open economy. We emphasize two transmission mechanisms: the cost channel, by which wage government spending and labor taxes raise the real wage firms must pay, and the exchange rate channel, by which the nominal exchange rate shifts induced by fiscal policy have real effects if (some) prices and wages are sticky. The latter channel implies that changes in wage government spending or in labor taxation should have different effects under flexible than under fixed exchange rates. In a 1964-93 panel of OECD countries we find significant evidence for both channels. Moreover, we find that the real product wage and profitability are more responsive than quantities (employment and output) to fiscal policy innovations.
\end{abstract}

*Lane: plane@tcd.ie; Perotti: Roberto.Perotti@IUE.it. We thank the anonymous referees, Olivier Blanchard, Jeffrey Sachs and participants in seminars at Columbia, Harvard, University of British Columbia, University of Washington and the NBER International Lunch for comments on a previous version of this paper. All errors are our own. 


\title{
The Importance of Composition of Fiscal Policy: Evidence from Different Exchange Rate Regimes
}

\begin{abstract}
We study the macroeconomic effects of fiscal policies in an open economy. We emphasize two transmission mechanisms: the cost channel, by which wage government spending and labor taxes raise the real wage firms must pay, and the exchange rate channel, by which the nominal exchange rate shifts induced by fiscal policy have real effects if (some) prices and wages are sticky. The latter channel implies that changes in wage government spending or in labor taxation should have different effects under flexible than under fixed exchange rates. In a 1964-93 panel of OECD countries we find significant evidence for both channels. Moreover, we find that the real product wage and profitability are more responsive than quantities (employment and output) to fiscal policy innovations.
\end{abstract}

\section{Introduction}

In this paper we study the short-run macroeconomic effects of shifts in fiscal policy in an open economy. We are especially interested in two questions. One is the importance of the composition of a given movement in fiscal policy. The other is whether the exchange rate regime makes a difference in the transmission of fiscal policy.

Research on recent fiscal consolidations in the OECD has highlighted the importance of composition in the success and persistence of fiscal reforms. As argued by Giavazzi and Pagano (1990) and formalized by Bertola and Drazen (1993), the consolidations in Denmark and Ireland in the mid-1980s were associated with a macroeconomic boom, rather than a recession, because they were mainly based on expenditure cuts rather than tax increases. Alesina and Perotti (1995, 1997a) and Alesina and Ardagna (1998) show that, controlling for the size of the budget deficit reduction, those adjustments that were implemented by cutting government transfers and public wages have been much more persistent than those achieved by increasing taxes. 
One reason the composition of a fiscal reform may be important is that it matters for the macroeconomic effects of a shift in fiscal policy. We start from the simple observation that, to different degrees, all industrialized countries are open economies: therefore, an understanding of how fiscal policy affects the tradable (here, manufacturing) sector is crucial for an understanding of the overall macroeconomic effects of fiscal policy. We consider four key indicators of the performance of the tradable sector: employment, output, the real product wage, and profitability.

Our focus on these variables is motivated by the observation that the labor market is a key channel by which fiscal policy movements affect the non-government sectors of the economy. Even if the tradable sector does not rely on the domestic economy as a source of final demand, it must compete with the non-traded sector (including the government sector) for non-traded factors such as labor. For instance, an increase in government employment or wages shifts out the aggregate demand for labor and causes upward pressure on economy-wide wages. Similarly, the workings of the labor market determine the extent to which increases in labor taxes are shifted onto firms in the form of higher pre-tax wages. In turn, higher labor costs induce firms to scale back the levels of employment and output and depress profitability. This cost channel is a primary mechanism by which fiscal policy affects the performance even of sectors that sell exclusively to foreign customers and hence are insulated from the level of aggregate demand in the domestic economy.

In the presence of sticky prices or wages, fiscal policy affects macroeconomic performance via a second channel, the exchange rate channel. For instance, an increase in government spending that generates nominal appreciation hurts the profitability of firms in the traded sector if they face exogenous foreign currency prices and domestic nominal wages are not fully flexible. We investigate this issue formally by conditioning responses to fiscal policy shifts on the exchange rate regime in place in each country in each time period. ${ }^{1}$

We construct a panel data set of up to seventeen OECD countries for the

${ }^{1}$ At the level of casual empiricism, many economists and policy-makers have argued that devaluation was an essential ingredient in the success of the 1987 Irish fiscal consolidation (see e.g. Alogoskoufis (1992) for an exposition of this view). Similarly, it is widely believed that the 1992 devaluations in the UK and Italy had a large positive impact on the international competitiveness of firms in those countries (see e.g. European Commission (1994)). 
period 1964-1993. In studying the composition of fiscal policy, we concentrate on government spending on goods and services on the expenditure side, and distinguish between its wage and non-wage components. On the revenues side, we consider labor taxation (i.e. personal income taxes, social security taxes, and payroll taxes). We show that the distinction between the various parts of the budget turns out to be crucial. Previewing our empirical results, the most important finding is that increases in wage government spending on goods and services raise the real product wage and depress profitability in the traded sector. Moreover, the effects on the real wage and profitability are significantly larger under a flexible exchange rate regime. With a few exceptions, that we note in due course, these and other results are consistent with the model of partial wage and price stickiness that we present in section 2 below.

To the best of our knowledge, the previous open-economy literature has not emphasized the composition effects of fiscal policy or jointly examined the cost and exchange rate channels. A number of papers are antecendents to various aspects of our contribution. Helpman (1976 and 1977) studies the crowding out effect of government spending in the non-traded sector on the level of production in the traded sector. De Gregorio, Giovannini and Wolf (1994) and Froot and Rogoff (1991) find evidence that the level of aggregate government consumption influences the relative price of tradables to nontradables. Alesina and Perotti (1997b) study empirically the effects of fiscal policy on relative unit labor costs, and the dependence of these effects on the degree of unionization of labor markets. Mendoza and Tesar (1998) emphasize the supply side effects of tax policies in open economies. Frenkel, Razin and Yuen (1996) focus on the fiscal deficit, and study theoretically wealth and intertemporal substitution effects in the context of a two-country, two-period model. Stockman and Ohanian (1993) also write a model with partial flexibility.

Finally, we note that our results on the open-economy dimension are complementary to other empirical studies on the effects of fiscal policy. In panel regressions on a similar sample to that used here, Giavazzi and Pagano (1996), Giavazzi, Jappelli and Pagano (1998), and Perotti (1999) investigate the response of private consumption to changes in various components of the government budget; Alesina, Ardagna, Perotti and Schiantarelli (1999) study the response of investment.

The plan of the paper is as follows. As a foundation for the empirical work, section 2 presents a simple model of fiscal policy in an open economy, 
formalizing the cost and the exchange rate channels discussed above. Section 3 develops the solution of the model under full price and wage flexibility first and then under price and wage stickiness. Section 4 discusses the data and the econometric specification. Section 5 presents the empirical results, while section 6 discusses their robustness: the relevant tables for this robustness exercise can be found on this journal's web site. ${ }^{2}$ Section 7 concludes.

\section{The model}

The traditional Mundell-Fleming model is not well equipped to deal with the main points we wish to emphasize. In the presence of full price rigidity, supply-side factors are unimportant in the short-run since it is assumed that the level of demand determines output. In that environment, fiscal policy (government spending or taxation) only operates via an aggregate demand channel. Moreover, for a small open economy that sells all its output on international markets at fixed world prices, the level of domestic demand is irrelevant for output and only affects the trade balance. A two-sector version of the Mundell-Fleming model that distinguishes between nontraded and traded goods does allow a demand channel even for a small economy: government spending on nontradables has an expansionary effect on that sector. However, the supply-side channel remains absent.

In what follows, we propose a two-sector model that allows fiscal policy to have an impact on supply conditions but retains sufficient nominal rigidities that the exchange rate regime matters for the transmission of fiscal policy. For realism, we model a non-traded non-market government sector as using labour to produce goods for its own consumption; thus, an increase in government wage consumption has a demand effect by raising the government's and therefore total labor demand. The other sector consists of private firms that employ labour to produce goods that are sold on world markets. These firms possess some market power (demand curves are downward-sloping) but local demand conditions are unimportant: home consumers are a negligible fraction of world demand. Fiscal policies affect this sector via a supply channel - changes in government employment or labor taxes affect real wages - and via the nominal exchange rate, in the case of a floating exchange rate system and partial nominal rigidities.

\footnotetext{
${ }^{2}$ http://www.elsevier.com/homepage/sae/econbase/pubec/.
} 
More formally, we model an open economy in which domestic private firms sell their output on world markets. The home economy is small: for simplicity we make the extreme - and standard - assumption that domestic consumers have zero impact on the levels of demand for domestic or foreign traded products. Firms have monopolistic power in the market for the good they produce and thereby face downward-sloping demand schedules: hence, if cost pressures force a price increase, output and employment decline. For simplicity, we present the model in the case of a generic downward sloping demand function and a generic upward sloping labor supply function. ${ }^{3}$

As was discussed in the introduction, we focus on three fiscal policy instruments: the wage and the non-wage components of government spending on goods and services, and taxes on labor. ${ }^{4}$ In modelling wage government spending, our assumption is that the government announces it will hire $L_{g}$ workers. In order to avoid modelling a segmented labor market, we assume that the government hires from an integrated labor pool and the average wage prevails in both the private and public sectors. The wage is determined by the equilibrium in the labor market: hence, in formulating its budgetary policy, the government takes into account the impact of an increase in government employment on the wage rate and hence on its total expenditure. Non-wage government spending falls mostly on privately-produced goods, and therefore in our model it would have no effects on aggregate labor demand, the wage, and costs since domestic demand is only a negligible component of final demand in an open economy. In a richer model, that includes for instance also a private non-tradables sector, ${ }^{5}$ non-wage government spending could have similar effects on labor demand as wage government spending if it were biased toward non-tradables. ${ }^{6}$ This is essentially an empirical question and we thereby allow a role for nonwage government spending in our empirical work. Finally, for simplicity, we model labor taxes as a linear tax rate $\tau$ on the wage $W$.

\footnotetext{
${ }^{3}$ In an earlier working paper version, we presented an explicit solution in the case of monopolistic competition with constant elasticity of substitution among different goods, and with an upward-sloping labor supply function derived from the equilibrium in a unionized labor market.

${ }^{4}$ Since our fiscal channels would operate even in a dynamic model that exhibits Ricardian equivalence, we are concerned with the direct effects of government spending and taxation policies rather than any impact via the levels of the fiscal deficit and public debt.

${ }^{5}$ Recall that we already have a non-traded sector in our model, the government sector.

${ }^{6}$ See for instance Helpman (1976) and Frenkel, Razin and Yuen (1996).
} 
Output is produced using only labor in both the private sector and the government sector (the latter identified by the subscript " $g$ "):

$$
Y=R(L) ; \quad Y_{g}=L_{g}
$$

where the first and second derivatives are $R_{1}>0$ and $R_{11} \geq 0 .{ }^{7}$ We denote total employment - the sum of private and government employment - as $L_{T}=L+L_{g}$. Aggregate labor supply is governed by an upward sloping labor supply curve:

$$
L_{T}^{s}=F\left(\frac{W(1-\tau)}{S}\right) \quad F_{1}>0
$$

where $S$ is the exchange rate, expressed as units of domestic currencies per unit of foreign currency (so that an increase in $S$ represents a depreciation of the domestic currency). Note that $S$ is also the CPI, since the composite consumption good is imported and its exogenous foreign currency price is normalized to $1 .{ }^{8}$ Thus, (2) says that aggregate labor supply is an increasing function of the real after-tax consumption wage. If we think of labor supply as being controlled by unions (as for instance in Alesina and Perotti (1997b) or in a previous version of this paper), the elasticity of labor supply embodied in the $F()$ function is a reduced-form aggregate concept, rather than reflecting an individual agent's labor supply elasticity. ${ }^{9}$

Given the single-factor production technology, labor demand in the private sector is driven by the foreign demand for private domestic output: ${ }^{10}$

$$
L^{d}=G\left(P^{*}\right) \quad G_{1}<0
$$

where $P^{*}$ is the price, in foreign currency, of tradable goods produced at home (which, under our assumptions, are all exported). Thus, we model the product market as imperfectly competitive: the higher is $P^{*}$, the lower is output demand and hence the level of employment.

\footnotetext{
${ }^{7} R_{11}=0$ corresponds to the constant returns case. $R_{11}>0$ implies the presence of increasing returns. For instance, increasing returns may be present if production requires a fixed labor input in addition to a variable labor input.

${ }^{8}$ We assume the CPI excludes government goods whose implicit price is given by the level of government wages.

${ }^{9}$ We adopt a general specification for the labor supply function, since our results do not depend on the presence of labor unions.

${ }^{10}$ Let output demand be $Y^{d}=J\left(P^{*}\right), J_{1}<0$. It follows that labor demand is $L^{d}=$ $R^{-1}\left[J\left(P^{*}\right)\right]=G\left(P^{*}\right)$.
} 
Export prices are set in buyers' currency and are a positive function of the marginal cost, also expressed in foreign currency. In this model with one factor, the marginal cost is equal to labor compensation $W(1+v)$, i.e. the wage paid to the employee plus any labor tax paid by the employer. The effects of an increase in the labor tax paid by the employer $v$ are qualitatively identical to those of an increase in $\tau$. For this reason and to simplify the notation, we assume $v=0$ from now on, and do not distinguish explicitly between wage and compensation. Hence the marginal cost is simply the real consumption wage, and

$$
P^{*}=H\left(\frac{W}{S}\right) \quad H_{1}>0
$$

The function $H()$ is linear in the monopolistic competition case but we could allow $H_{11}<0$ also. This would be the case if firms were reluctant to fully pass on cost increases to consumers. For instance, in the customer-loyalty model of Phelps (1994), firms do not fully pass on costs increases since a rise in price increase has a negative impact on market share. ${ }^{11}$

As it is standard, we assume the money supply is held fixed under a floating exchange rate regime. Accordingly, the exchange rate is determined by money demand, and therefore by domestic real GDP $Q$ (as it is the case in any transactions-based theory of money demand). We assume velocity is fixed: an increase in GDP increases the transactions demand for money and hence causes an appreciation of the exchange rate

$$
S=V(Q) \quad V_{1}<0
$$

where real GDP is the sum of real value added in the private and government sector:

$$
Q=\frac{W}{S} L_{g}+P^{*} Y
$$

\section{The effects of fiscal policy}

We can now discuss the effects of changes in government spending or taxes on output, employment, costs, the exchange rate and profitability in the traded sector.

\footnotetext{
${ }^{11}$ Alternatively, as in Ball and Romer (1990), such real rigidity may arise from imperfect information that makes existing customers more responsive to price increases than prospective new customers are to price decreases.
} 


\subsection{Measures of cost and profitability}

We consider two measures of costs and profits: the real product wage $\omega$ and "profitability" $\pi$, as measured by the ratio of the output price to unit labor costs. The real product wage is the ratio of the nominal wage to the domestic output price $^{12}$

$$
\omega=\frac{W}{S P^{*}}=\frac{W}{S} / H\left(\frac{W}{S}\right)
$$

Note that the real product wage thus defined is just the inverse of the markup of the price on the marginal cost.

Now let unit labor costs in the private sector be the ratio of nominal labor costs (in the foreign currency) to real value added: $U L C=W L / S Y$. We define profitability in the private sector as the ratio of the output price to unit labor $\operatorname{costs}^{13}$

$$
\pi=\frac{P^{*}}{U L C}=\frac{S P^{*} Y}{W L}
$$

When $P^{*}$ is the value added deflator, this definition of profitability is equivalent to the inverse of the profit share in value added. Also, under constant returns ( $Y$ proportional to $L$ ), $P^{*} / U L C$ is proportional to the markup, hence it is proportional to the inverse of the real product wage.

\subsection{Flexible wages and prices}

As a benchmark, we now work out the effects of fiscal policy on relative prices, wages, employment, and output in the case of perfectly flexible domestic prices and wages; in the next subsection, we allow for partial stickiness in prices and wages.

Because the real consumption wage is equal to the marginal cost, for illustrative purposes it is useful to start from the effects of fiscal policy on the real consumption wage; this and the markup will determine the effects on the output price, hence on output and employment, hence on the real product wage and profitability.

\footnotetext{
${ }^{12}$ Note the difference with the real consumption wage, which is the ratio of the nominal wage to the consumer price index $S$.

${ }^{13}$ This is a widely used measure of profitability in international comparisons. Note that the effects of fiscal policy shocks would be the same if we used an alternative definition of profitability, like operating profits divided by the capital stock.
} 
An increase in $L_{g}$ raises total labor demand; from equation (2), for labor supply to increase and match the extra labor demand, the real after-tax consumption wage must increase; hence, for a given $\tau$, the real consumption wage $W / S$ must increase. In addition, from equation (2), if the labor tax rate $\tau$ increases, the real consumption wage $W / S$ must increase to compensate for the higher tax rate. Letting a tilde ${ }^{\tau}$ denote the equilibrium value of a variable in the case of flexible wages and prices, we have

$$
(\widetilde{W / S})=\frac{q\left(L_{g}\right)}{1-\tau} \quad q_{1}>0
$$

Now consider the effects of fiscal policy on prices, output and employment. $>$ From (4), the real price $P^{*}$ is a mark-up over the real consumption wage $W / S$. We have just shown that the real consumption wage increases when $L_{g}$ or $\tau$ increase. Hence:

$$
\widetilde{P^{*}}=H[(\widetilde{W / S})]=\Lambda\left(L_{g}, \tau\right) \quad \Lambda_{1}>0 ; \quad \Lambda_{2}>0
$$

Thus, when $L_{g}$ or $\tau$ increase, the real price $\widetilde{P^{*}}$ also increases. Because domestic firms face a downward sloping demand for exports, private output and therefore private employment fall:

$$
Y=\gamma\left(L_{g}, \tau\right) \quad \gamma_{1}<0 ; \quad \gamma_{2}<0
$$

Hence, the real consumption wage, the real output price, employment, and real output are all independent of $S$; as a consequence, the effects of fiscal shocks on these variables are independent of the exchange rate regime.

If $H_{11}=0$, as in monopolistic competition, the real product wage is independent of $W / S$. If $H_{11}<0$, as for instance in the Phelps model, then the real price $\widetilde{P^{*}}$ increases less than the real consumption wage; as a consequence, the real product wage increases whenever $W / S$ rises, for example in response to either wage government spending or labor tax increases.

Under constant returns, the output/employment ratio $Y / L$ is constant and our measure of profitability, $P^{*} / U L C$, is proportional to the inverse of the real product wage; hence, an increase in wage government spending or in labor taxes does not change profitability if $H_{11}=0$; if instead $H_{11}<0$, the real product wage increases and profitability falls when wage government spending or labor taxation rise. Under increasing returns, regardless of the 
value of $H_{11}$, the output/employment ratio $Y / L$ falls as the real price $\widetilde{P^{*}}$ increases, hence profitability falls. ${ }^{14}$

But what happens to the exchange rate $S$ ? The answer depends on what happens to GDP. When $L_{g}$ increases, we have seen that government value added increases and private value added falls; in appendix A, we show that the net effect is that total GDP increases (for plausible parameter ranges) and therefore the nominal exchange rate appreciates. The intuition is that GDP will increase so long as the (negative) elasticity of the real wage with respect to wage government consumption is not too large. This will be the case when the size of the government sector is not too large and labor supply and labor demand from private firms are not too inelastic. When $\tau$ increases, government value added does not change, but we know from (11) that private value added falls; hence, total GDP unambiguously falls, and the exchange rate depreciates.

In summary, we have shown that under the assumption of perfect wage and price flexibility all relevant quantities are just a function of the real consumption wage $W / S$, and therefore they are independent of the exchange rate $S$. The effects of fiscal policy are therefore independent of the exchange rate regime. In addition, under constant returns to scale the real product wage, the markup and profitability are independent of fiscal policy if $H_{11}=$ 0 ; if $H_{11}<0$, in contrast, real consumption wage increases are not fully passed through into prices and a fiscal expansion raises the real product wage and depresses the markup and profitability. Under increasing returns, profitability declines regardless of the value of $H_{11}$; and it declines more than in the constant returns to scale case, because the fall in output is associated with a reduction in the output-labor ratio.

\subsection{Nominal rigidities}

To obtain a regime effect, we now assume that both prices and wages are only partially flexible. ${ }^{15}$ A convenient formulation is to assume that a proportion

\footnotetext{
${ }^{14}$ Labor hoarding would have the same impact as increasing returns, with $Y / L$ an increasing function of $Y$. For brevity, we just use the term "increasing returns" in the text.

${ }^{15}$ We do not strictly need that wages are subject to a nominal rigidity: all that is required is that the nominal wage $w$ does not move one-for-one with the nominal exchange rate $S$. This can also be achieved if $S$ had only a partial impact on the CPI due to the additional consumption of, say, a nontraded good, and the relative price of the nontraded good falls
} 
$\lambda$ of sectors set prices and wages in a flexible manner and $(1-\lambda)$ set prices and wages in advance of the realization of shocks. It follows that average prices and wages follow the partial adjustment processes:

$$
\begin{aligned}
& \log P^{*}=\lambda \log \widetilde{P^{*}}+(1-\lambda) \log P_{f}^{*} \\
& \log W=\lambda \log \widetilde{W}+(1-\lambda) \log W_{f}
\end{aligned}
$$

where $P_{f}^{*}$ and $W_{f}$ are the predetermined values of prices and wages in "sticky" sectors. ${ }^{16}$

Now consider what happens when wage government spending increases unexpectedly, starting from an equilibrium situation where $P^{*}=\widetilde{P^{*}}$ and $W=\widetilde{W}$. Again, conceptually it is useful to start from the effect on the real consumption wage and then follow the same logic as in the case of fully flexible wages and prices.

As labor demand increases, the nominal wage and the real consumption wage must increase in the flexible sectors. Starting from a situation of full equilibrium and the same $S$ in the two regimes, from (9) the effect on the average nominal wage $W$ is:

$$
\frac{d \log W}{d \log L_{g}}=\lambda \frac{d \log \widetilde{W}}{d \log L_{g}}
$$

since the nominal wage is free to adjust only in the flexible sectors. Hence, the change in the average real consumption wage $W / S$ under the two regimes is

$$
\frac{d \log (W / S)}{d \log L_{g}}= \begin{cases}\lambda \frac{d \log (\widetilde{W / S})}{d \log L_{g}} & \text { under f.e.r. } \\ \lambda \frac{d \log (\widetilde{W / S})}{d \log L_{g}}+(\lambda-1) \frac{d \log S}{d \log L_{g}} & \text { under fl.e.r. }\end{cases}
$$

when $S$ depreciates. For simplicity, we assume wages are partially sticky in order to avoid having to introduce an extra consumption good into the analysis.

${ }^{16}$ We can think of these being set at optimal expected values before the realization of shocks. 
In both regimes, there is upward pressure on the real consumption wage that emanates from the flexible sectors. Under floating exchange rates, there is an additional effect on average wages: the increase in $L_{g}$ causes an appreciation (a fall in $S$ ). In sectors where wages are sticky, the appreciation means that real consumption wages rise and therefore a bigger increase in the average real consumption wage $W / S$ is observed under floating exchange rates than under fixed exchange rates. The first term $\lambda\left(d \log (\widetilde{W / S}) / d \log L_{g}\right)$ in equation (15), which is common to both regimes, is a fraction $\lambda$ of the effect with perfectly flexible prices and wages; hence, it is independent of the exchange rate: we call it the cost channel of fiscal policy. ${ }^{17}$ The term $(\lambda-1)\left(d \log S / d \log L_{g}\right)$, which appears only under flexible exchange rates, represents the effects of fiscal policy via the exchange rate: we call it the exchange rate channel of fiscal policy.

From equation (12), the average export price increases by

$$
\frac{d \log P^{*}}{d \log L_{g}}=\lambda \frac{d \log \widetilde{P^{*}}}{d \log L_{g}}=\lambda \phi \frac{d \log (\widetilde{W / S})}{d \log L_{g}}
$$

where the pass-through coefficient $\phi=1$ if $H_{11}=0$ and $0<\phi<1$ if $H_{11}<0$. In flexible sectors, the increase in real consumption wages that is induced by the government spending expansion is (at least partially) passed through into export prices.

In turn, the impact on private output is given by

$$
\frac{d \log Y}{d \log L_{g}}=-\psi \frac{d \log P^{*}}{d \log L_{g}}
$$

where we assume a log-linear relation between price and output. Because private output falls, private employment also falls. It is important to note that the decline in output and employment is the same in both exchange rate regimes. The reason is that quantities are determined by the level of output prices; output prices adjust to changes in fiscal policy only in flexible sectors; but these sectors also adjust fully to any change in the nominal exchange rate, thus eliminating a regime effect on quantities.

\footnotetext{
${ }^{17}$ Strictly speaking, $\tilde{w}$ is not the same under partial price stickiness versus full price stickiness, since wage increases are not fully passed into prices and hence output and labor demand is less elastic with respect to wages. We ignore this minor complication.
} 
From equations (15) and (16), the effect of a change in $L_{g}$ on the average real product wage $\omega$ is

$$
\frac{d \log \omega}{d \log L_{g}}= \begin{cases}(1-\phi) \lambda \frac{d \log (\widetilde{W / S})}{d \log L_{g}} & \text { under f.e.r. } \\ (1-\phi) \lambda \frac{d \log (\widetilde{W / S})}{d \log L_{g}}+(\lambda-1) \frac{d \log S}{d \log L_{g}} & \text { under fl.e.r. }\end{cases}
$$

Under flexible exchange rates, the average real product wage increases more than under fixed exchange rate: the intuition is that the nominal exchange rate appreciation under flexible exchange rates pushes up the real product wage in the sectors that do not adjust. Note that, as in equation (15), one can also identify a cost channel and an exchange rate channel of fiscal policy on profitability in equation (18).

Under constants returns, from the formula for profitability (equation (8)), we have $d \log \pi / d \log L_{g}=d \log P^{*} / d \log L_{g}-d \log (W / S) / d \log L_{g}$. Therefore, the change in average profitability is just the opposite of the change in the average real product wage: thus, profitability falls more under flexible exchange rates, as the nominal appreciation increases the marginal cost $W / S$ even in the sectors that do not adjust wages and prices. Under increasing returns, the fall in profitability is even larger since the output decline means a fall in the output-labor ratio, compounding the negative effect of a rise in the real product wage.

The following table summarizes how the effects of a change in $\mathrm{L}_{g}$ depend on the degree of returns to scale and on the value of $\phi$; the table also displays the direction of the exchange rate regime effect on each variable (the superscripts "F" and "P" indicate a flexible and a pegged exchange rate regime, respectively). 
Table I: effects of an increase in $\mathbf{L}_{g}$

\begin{tabular}{|c|c|c|}
\hline CRTS & $\begin{aligned} \Delta Y^{F} & =\Delta Y^{P}<0 \\
\Delta L^{F} & =\Delta L^{P}<0 \\
\Delta(Y / L)^{F} & =\Delta(Y / L)^{P}=0 \\
\Delta \omega^{F} & =\Delta \omega^{P}=0 \\
\Delta \pi^{F} & =\Delta \pi^{P}=0\end{aligned}$ & $\begin{aligned} \Delta Y^{F} & =\Delta Y^{P}<0 \\
\Delta L^{F} & =\Delta L^{P}<0 \\
\Delta(Y / L)^{F} & =\Delta(Y / L)^{P}=0 \\
\Delta \omega^{F} & >\Delta \omega^{P}>0 \\
\Delta \pi^{F} & <\Delta \pi^{P}<0\end{aligned}$ \\
\hline IRTS & $\begin{aligned} \Delta Y^{F} & =\Delta Y^{P}<0 \\
\Delta L^{F} & =\Delta L^{P}<0 \\
\Delta(Y / L)^{F} & =\Delta(Y / L)^{P}<0 \\
\Delta \omega^{F} & =\Delta \omega^{P}=0 \\
\Delta \pi^{F} & <\Delta \pi^{P}<0\end{aligned}$ & $\begin{aligned} \Delta Y^{F} & =\Delta Y^{P}<0 \\
\Delta L^{F} & =\Delta L^{P}<0 \\
\Delta(Y / L)^{F} & =\Delta(Y / L)^{P}<0 \\
\Delta \omega^{F} & >\Delta \omega^{P}>0 \\
\Delta \pi^{F} & <\Delta \pi^{P}<0\end{aligned}$ \\
\hline
\end{tabular}

"CRTS": constant returns to scale; "IRTS": increasing returns to scale. $\phi=1$ : complete pass through"; $\phi<1$ : incomplete pass through.

The cost channel of labor taxation is similar. As taxes go up, imperfectly elastic labor supply means that the real consumption wage $W / S$ must rise. As a result, prices increase, output and employment fall, the real product wage rises and profitability falls. The exchange rate channel, however, now works in the opposite direction, since total GDP falls and therefore in a flexible exchange rate regime the exchange rate depreciates in response to the tax hike. This depreciation dampens the increase in the product wage and the fall in profitability arising from an increase in labor taxes. As with government employment, and for the same reasons, the effect of a change in labor taxes on private output and employment is independent of the exchange rate regime. Table II summarizes the effects of an increase in the tax rate, depending on the value of $\phi$ and on the degrees of returns to scale. 
Table II: effects of an increase in $\tau$

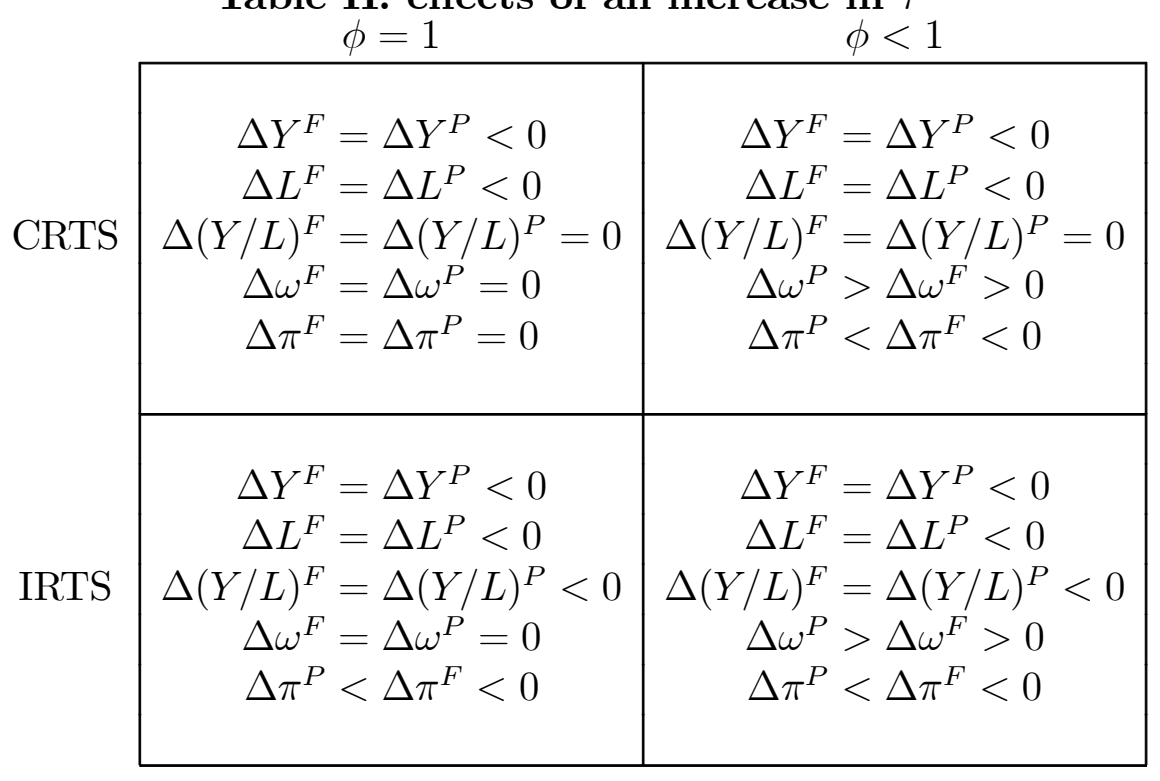

In summary, our model predicts that an increase in wage government spending raises the real wage and reduces profitability in both exchange rate regimes but that the effect is bigger under flexible exchange rates. Symmetrically, the model predicts that an increase in labor taxation will cause an increase in the real product wage and a decline in profitability but that the effect is stronger under pegged exchange rates. With respect to quantities, an increase in wage government spending or labor taxation reduces output and employment in the private tradable sector. Since the quantity response is driven by the change in output prices, the output and employment effects are the same across exchange rate regimes.

\subsection{Discussion and extensions}

There are three important points to note about the model. First, we have assumed that both prices and wages do not adjust fully to fiscal shocks. If only prices were sticky, $W / S$ would be independent of $S$ and there would be no exchange rate channel in the transmission of fiscal policy to real consumption wages. With respect to profitability and the real product wage, an exchange rate channel would still operate even if wages were perfectly flexible so long as prices were partially sticky. However, if prices were fully rigid, there would be no short-run output and employment effects from fiscal policy since there 
would be no increase in prices and hence no decline in world demand for the country's exportables. If only wages were sticky, there would be no effects on output or profitability under fixed exchange rates, since the output price would optimally adjust only to movements in the wage. ${ }^{18}$ Also, we have made a sharp distinction between "flexible" sectors in which both prices and wages are flexible and "rigid" sectors in which both are sticky. Other ways of introducing partial rigidity could allow a difference in the quantity response across exchange rate regimes. For example, in the case of a flexible-price firm dealing with sticky-wage workers, a nominal exchange rate depreciation leads to a fall in the real wage paid by firms and hence induces a decline in the output price. Again, we leave this open as an empirical matter.

Second, we assume firms preset prices in foreign currency units. If export prices were rather predetermined in terms of the domestic currency, exchange rate fluctuations would have no impact on the real product wage and the markup: the export price in domestic currency, $S P^{*}$, which appears in the numerator of (11), would be fixed and hence insensitive to exchange rate fluctuations; similarly, under constant returns, profitability would be independent of the exchange rate. However, this case would also generate a regime effect in quantities, since foreign-currency prices (and hence export sales) would now fluctuate with the exchange rate. Consistent with Engel (1999), the case we assume is empirically more relevant.

Third, the degree of flexibility $\lambda$ and the pass-through coefficient $\phi$ influence the magnitude of the effects of an increase in $L_{g}$ on quantities and profitability. With respect to the cost channel, the smaller is $\lambda$, the smaller the effects on the average output price and hence on quantities. A smaller $\lambda$ is also associated with a smaller increase in the average real consumption wage, since we assume the same degree of flexibility in wages as in prices. If $\phi<1$, the smaller also is the increase in the real product wage $\omega$. With increasing returns, since the effect on output and employment is smaller, so is the fall in $Y / L$; because $\pi=(Y / L) / \omega$, the negative effect on profitability is also smaller when $\lambda$ is smaller. With respect to the exchange rate channel, a smaller $\lambda$ magnifies the impact of exchange rates on profitability by increasing the degree of nominal rigidity. However, since a smaller $\lambda$ also attenuates the quantity response to fiscal innovations, the magnitude of the change in

\footnotetext{
${ }^{18}$ Under flexible exchange rates and sticky wages, nominal appreciation would lead to a higher real wage, which firms would pass through into prices and hence output and employment would fall.
} 
the exchange rate is diminished, which is an offsetting effect. In analysing the case of an increase in taxation, variation in $\lambda$ has similar effects. ${ }^{19}$

\section{The data and specification}

We test our model on a panel of yearly data, covering between fourteen (in the high-quality sample) and seventeen (in the largest sample) countries. ${ }^{20}$ The data extend over the 1964-93 period in all countries in the high-quality sample, with the exceptions of Denmark (starting date 1967), France (ending date 1992) and Norway (starting date 1966 and ending date 1991); we also exclude the years after 1989 in Germany because of the break in all its series due to the reunification. Thus, the high-quality sample is a nearly balanced panel.

The Data Appendix (available on this journal's web site) provides a complete description of the data and their sources. Here we illustrate the main features of our dataset. All our data on government expenditure and revenues come from the OECD Economic Outlook dataset. ${ }^{21}$ According to international guidelines on national income accounting followed by the OECD, government spending on goods and services is divided into current spending (i.e., government consumption) and capital spending (i.e., government investment). Hence, following the OECD classification, we measure the wage component of government spending on goods and services $(W G S)$ as the wage

\footnotetext{
${ }^{19}$ In general, the impact of a smaller $\phi$ on the transmission of fiscal shocks is ambiguous. To see why, compare two economies, the first with $\phi=1$ and the second with $\phi<1$. We have seen that, when $L_{g}$ increases, the real wage $\omega$ remains constant in the first and increases in the second economy; in addition, $\phi<1$ implies that labor demand is less elastic, hence a given increase in $L_{g}$ causes $W / S$ to increase more in the second. Hence, it cannot be established a priori in which of the two economies $P^{*}$ increases more. As a consequence, we also do not know whether employment and output increase more when $\phi=1$ or when $\phi<1$.

${ }^{20}$ The countries in the high-quality sample are: Australia, Belgium, Canada, Denmark, Finland, France, Germany, Italy, Japan, Netherlands, Norway, Sweden, United Kingdom, and USA. In our robustness analysis, we also add Austria, Ireland and Spain, whose data come from different sources than the one we use for the high quality sample: see the web appendix for details and results.

${ }^{21}$ For some country-years - particularly in the 1960s - this source has been supplemented with the OECD National Income Accounts database. The definitions and structure of this dataset are identical to those of the Economic Outlook; hence, the fiscal data are consistently defined both over time and across countries.
} 
component of government consumption; we measure the non-wage component of spending on goods and services $(N W G S)$ as the sum of the non-wage component of government consumption and of government capital expenditure. Our measure of labor taxation $(L T A X)$ consists of the sum of social security taxes $(S S R G)$ and of direct taxes on households $(T Y H)$, also from the Economic Outlook. ${ }^{22}$

To ensure that movements in taxes are not just a reflection of cyclical fluctuations in the economy, we cyclically adjust labor taxes. We follow the methodology suggested by Blanchard (1993), consisting in evaluating this year's taxes at last year's output; to do this, we use real output elasticities of labor taxes provided by OECD in Giorno et al. (1995). ${ }^{23}$

In the model, we focused on five key variables: employment, output, the real product wage, the exchange rate and profitability, all in the traded sector. We take the traded sector to be the manufacturing sector, a common and reasonable assumption that maximizes the availability of data and their comparability across countries. In fact, for all fourteen countries in our highquality sample, the four variables above can be constructed from the OECD Intersectoral Database as follows: ${ }^{24}$

Employment $(L)$ : dependent employment (= number of employees) in manufacturing;

Output $(Y)$ : real value added in manufacturing;

\footnotetext{
${ }^{22}$ Direct taxes on households also includes some direct taxes that do not fall on income, like certain property taxes. However, the breakdown between income and non-income direct taxes is not always available; we have chosen to use the Economic Outlook measure to ensure comparability across countries and over time.

${ }^{23}$ These elasticities start in 1978, and are updated at about 3 year intervals. For the years before 1978, we use the 1978 elasticity. This is likely to be a rather innocuous approximation, because within each country these elasticties change minimally over time, and in any case the period of substantial tax reforms is generally the 1980s.

${ }^{24}$ For a few country-years, especially at the beginning of the sample, we supplement the OECD Intersectoral Database with other sources: the International Labor Office Yearbook of Labor Statistics for manufacturing employment, the OECD Economic Outlook for unit labor costs in manufacturing, and the OECD National Income Accounts for value added in manufacturing. These are also the sources we use for Austria and Spain. For Ireland, we also use data provided directly to us by that country's Central Statistical Office. Note that, except for the employment data at the beginning of the sample in a few countries, all our data come from OECD sources, which ensures a good comparability of the series. In fact, when the same series is available both from, say, the Intersectoral Database and the National Income Accounts, they are always virtually identical.
} 
Real product wage $(\omega)$ : nominal compensation per employee / value added deflator in manufacturing;

Exchange Rate $(S=E R)$ : nominal effective exchange rate;

Profitability $(\pi)$ : value added deflator in manufacturing / unit labor costs in manufacturing;

where unit labor costs are defined as total nominal compensation of employees divided by real value added. Thus, $\pi$ is equal to the inverse of the share of labor in manufacturing value added.

We allow for different responses to fiscal policy across exchange rate regimes by interacting each fiscal policy variable with the indicator variables $P$ and $F$, which stand for pegged and flexible exchange rate regimes respectively. We divide our sample period into pegged and flexible exchange rate regimes as follows. ${ }^{25}$ For all countries, the period 1963-1972 is considered pegged. ${ }^{26}$ The subsequent period is considered flexible, except for the 19791993 period for Belgium, Denmark, France, Germany, and the Netherlands, which is considered pegged. Italy is considered pegged from 1979 until 1992, and flexible afterwards as a consequence of Italy's exit from the ERM in September of 1992. Great Britain is considered fixed in 1990-91, and flexible afterwards, also because of the events following the September 1992 crisis. We recognize that this classification is necessarily subjective: for instance, one could argue that Italy's position after 1992 is closer to a flexible exchange rate regime than to a pegged exchange rate regime. However, our results are not sensitive to alternative classifications of these borderline cases. ${ }^{27}$ We end

\footnotetext{
${ }^{25}$ Since we desire a 0-1 dummy variable, some judgement is required in allocating the intermediate cases between pure fixes and pure floats. The IMF classification of exchange rate regimes, based on self-reporting by countries, contains several such intermediate cases and so does not neatly deliver a 0-1 categorisation. For this reason, some judgement calls are required. An alternative approach would be to classify exchange rate regimes according to the observed degree of exchange rate volatility but this is problematic for several reasons. First, the actual level of volatility depends on the volatility of the underlying shocks. Second, such a procedure would make OLS estimates inconsistent, since the exchange rate regime would be defined on the basis of the values of the dependent variable in an exchange rate equation.

${ }^{26}$ The exceptions are Canada, that floated its currency in 1970, and Germany and the Netherlands, that floated in 1971.

${ }^{27}$ Of the three countries that are not part of our high-quality sample, we classify Austria as belonging to a fixed exchange rate regime during the whole period, on the grounds that
} 
up with about an equal number years in the two regimes; 208 in the flexible exchange rate regime, 200 in the pegged exchange rate regime, for a total of 408 observations. When Austria, Ireland and Spain are included, the total number of observations increases to 488, with 232 in the flexible exchange rate regime and 256 in a peg.

We recognize that the possibility of realignments within the European Monetary System makes it a mixed system. Particularly at the beginning of the period, the frequent number of realignments may have made it closer to a flexible than to a pegged exchange rate regime. In the empirical part, we allow for a difference between years with and without realignments. As it turns out, our results are not sensitive to the treatment of realignments within the EMS. ${ }^{28}$ Although selection bias is always a potential problem when using exchange rate regime classifications, we are quite confident that in our case the results are not sensitive to selection bias in the choice of exchange rate regime. Recall that what we are estimating is the effect of a change in fiscal policy in year $t$ on manufacturing performance in year $t$, conditional on the exchange rate regime in place in year t. In the OECD, the persistent floaters (eg US or Japan) have a strong commitment to floating (e.g. due to country size and a desire for policy autonomy), which is unlikely to be much influenced by the current state of the manufacturing sector in the same year. Similarly, the peggers (mostly European countries) were pegged either for political reasons (e.g. a multilateral peg system within the European Union) and/or due to optimum currency area reasons (e.g. Austria pegging to Germany). The trend shift from pegging to floating in the early 1970s had several causes but the state of the manufacturing sector does not rank high in that list.

Finally, in addition to the fiscal variables, we include a proxy for the level of external demand as an additional control variable. This is to ensure that any fiscal effects are not just reflecting a correlation between fiscal policy and

the shilling has always been pegged to the D-mark, and exports to Germany account for more than 50 percent of all Austrian exports during this period. As in previous cases, our results are robust to alternative assumptions and do not change substantially if the 1973-1979 or the 1973-1990 periods for Austria are considered flexible. Ireland is treated like other members of the ERM and EMS: pegged until 1972, then flexible until 1978, then pegged again. Spain is considered pegged from 1990 on.

${ }^{28}$ The Bretton Woods system also witnessed some realignments: France devalued in 1969, the U.K. and Ireland in 1967; Germany and the Netherlands revalued in 1969. We deal with these realignments as we do with the much more frequent EMS realignments. 
international economic conditions.

Accordingly, our estimation framework is given by

$$
\begin{aligned}
\Delta X_{i t}= & P * \alpha_{i}+F * \alpha_{i}+P * \phi_{t}+F * \phi_{t}+ \\
& P * \Delta \bar{G}_{i t} * \bar{\beta}_{P}^{\prime}+F * \Delta \bar{G}_{i t} * \bar{\beta}_{F}^{\prime}+P * \Delta W Y_{i t}+ \\
& F * \Delta W Y_{i t}+P * \bar{Z}_{i t} * \bar{\theta}_{P}^{\prime}+F * \bar{Z}_{i t} * \bar{\theta}_{F}^{\prime}+\epsilon_{i t}
\end{aligned}
$$

where $X_{i t}$ is the macroeconomic variable of interest, $\alpha_{i}$ and $\phi_{t}$ are country and time fixed effects, and $\bar{G}_{i t}$ is a row vector of fiscal policy variables which include the logs of wage government spending on goods and services, nonwage government spending on goods and services, and labor taxes. ${ }^{29} W Y_{i t}$ is a weighted average of the log of the real GDP of all trading partners of each country, using trade weights. ${ }^{30} \bar{Z}_{i t}$ is a row vector of other controls, which includes a dummy variable for realignments, and a dummy variable for the 1974-75 oil shock, both interacted with the exchange rate regime dummies and with the fiscal policy variables.

All fiscal variables are expressed in real, per capita terms using the GDP deflator. All variables are then log-differenced. Note that the regime effect is operative only in the presence of unexpected changes in fiscal variables: if all movements in fiscal variables were perfectly predicted, the effects of fiscal policy would be the same in the two regimes. In our benchmark results, we do not attempt to separate the expected from the unexpected component of fiscal policy movements, a procedure that is always highly sensitive to the methodology adopted. In effect, we make the plausible assumption that on average changes in fiscal policy have an unanticipated component. For each variable, we ran the Im-Pesaran-Shin panel unit root test, allowing for a time trend and for 0, 1, 2 or 3 lags in the underlying ADF regressions. In no case could we reject the null of a unit root. ${ }^{31}$

\footnotetext{
${ }^{29}$ Allowing for country-specific intercepts is less restrictive than imposing a common intercept - there is no reason to believe manufacturing sectors in different countries experience identical drift growth rates in output, unit labor costs, profitability and real wages.

${ }^{30}$ The question arises of the endogeneity of $W Y$. However, in all our regressions we have year dummies, which capture the common demand and supply shocks. Thus, $W Y$ largely captures external (to the country) demand shocks that are orthogonal to the demand shocks caused by fiscal policy and to the common shocks.

${ }^{31}$ Note that the test-statistics we use to implement the Im-Pesaran-Wu test, $\bar{z}_{1 N T}$ in their notation, does not require a balanced panel (see Im, Pesaran and Wu (1995)). In any case, our panel is minimally unbalanced. Given the values of the test statistics, this clearly makes no difference for the results.
} 


\section{The effects of different budget items}

\subsection{Quantity variables}

Table 1 illustrates the response to fiscal policy changes of the two quantity variables in our model, output (column 1) and employment (column 2), and of their ratio (column 3). We include only those country-years that have data available for all the variables. Hence, the sample is exactly the same in all regressions in Tables 1 and 2, and since all variables are expressed in log differences, the coefficients in column 3 are identically equal to the difference between the coefficients in column 2 and 1 . All regressions of Tables 1 and 2 are based on the high-quality sample of 14 countries.

As discussed in section 3.3, we expect a negative relationship between wage government spending, $W G S$, or labor taxation, $L T A X$, on one hand, and employment or output in the manufacturing sector on the other: as $W G S$ or $L T A X$ increase, the pre-tax wage increases, and employment and output fall. We also expect smaller negative effects of changes in non-wage government spending on goods and services, $N W G S$, on employment or output. We also expect a positive effect of $W Y$ on employment, value added, and profitability in manufacturing.

From columns (1) and (2) in Table 1, the point estimates indicate that manufacturing value added and employment falls in response to an increase in $W G S$. However, the estimates are not statistically significant. The fact that there is no difference in quantity responses across regimes is consistent with our model: since quantities depend on the response of the flexible sectors that do not suffer from nominal rigidities, in our model there is also no regime effect on quantities. ${ }^{32}$ Note that the point estimates for $N W G S$ has a positive or at least much smaller negative impact on output and employment than $W G S$, and very little effect on employment, all of which is also consistent with our model.

Regarding the estimated effects of $L T A X$, we do observe a negative response of output to an increase in labor taxation but the employment co-

\footnotetext{
${ }^{32}$ If flexible-price firms faced average wages rather than the flexible wage, then a regime effect on quantities should exist since partial nominal wage stickiness means that average real wages are affected by the exchange rate (see equation (16)). However, even in that case, a lack of a regime effect on quantities could still be rationalized if, for some reason, firms are reluctant to pass through the effect of exchange rate fluctuations into export prices.
} 
efficients are small and statistically insignificant. These responses may be understated if our labor tax measure remains inadequately purged of its cyclical component. We cyclically adjust taxes with respect to changes of output; thus, any positive change in employment holding constant output will have a positive effect on taxes and employment, inducing a positive correlation between the two. For this reason, a proper cyclical adjustment is particularly important in the employment regressions, because labor taxes are a direct function of employment.

Column (3) of Table 1 displays the regression for the labor-output ratio. By construction, its coefficients are equal to the difference between the coefficients in columns (2) and (1). Because the coefficients of WGS in the output and employment regressions were small to start with, and with the same sign, they are even smaller and insignificant in column (3). A fortiori, the same conclusion applies to $N W G S$. However, we do observe a positive effect of $L T A X$ on the labor-output ratio. Recall that, under constant returns to scale, all these fiscal variables should have no effect on the labor-output ratio. As was pointed out in section 2, a positive point estimate could be rationalized for instance by a model with increasing returns to scale due to the presence of a fixed labor requirement or by labor hoarding.

Finally, we note that the external demand proxy $W Y$ works in the expected direction: an increase in $W Y$ raises domestic output and employment, although the former effect is not significant under pegged exchange rates.

Although the qualitative responses in Table 1 are broadly in line with our theoretical approach, the estimated coefficient magnitudes are small and typically insignificant. We turn next to an investigation of the responses of wages, profits and the exchange rate.

\section{2 "Price" variables}

Table 2 displays the effects of fiscal policy on the main "price" variables of the model, namely the real product wage, profitability, and the nominal effective exchange rate. Here the effects are substantial, and all in the direction predicted by our model.

Column (1) displays the real product wage regressions. ${ }^{33}$ As discussed in section 3.3, we expect $W G S$ and $L T A X$ to have a positive coefficient in

\footnotetext{
${ }^{33}$ Recall that the real product wage is just the inverse of the markup, so that these regressions can equivalently be interpreted as markup equations.
} 
the real product wage regression; we also expect the effects of $W G S$ to be stronger in a flex, and the effects of $L T A X$ to be stronger in a peg. In fact, for the real wage equation in column (1), WGS has coefficients of .03 in a peg and .36 in a flex, with the difference significant at the $4 \%$ level.

Also consistent with the theory, $L T A X$ has a positive and significant effect on the real product wage under a peg, and the point estimate for this effect is much stronger than in a flex: the estimated coefficients are .13 and -.01, respectively, with a p-value from an F-test on their difference of .13.

From its definition, the log change in profitability, as measured by the ratio of output price to unit labor costs, is identically equal to the log change in the employment-output ratio (column (3) of Table 1) less the log change in the real product wage (column (1) of Table 2)). Column (2) of Table 2 reports the benchmark profitability regression. As discussed in section 3.3, we expect an increase in $W G S$ to have a more negative effect on profitability under flexible exchange rates via the nominal appreciation that it induces. Conversely, an increase in $L T A X$ will have a less negative effect on profitability under flexible exchange rates, as the contractionary effect of labor taxation should generate a nominal depreciation.

Consistent with our model, an increase in $W G S$ is associated with lower profitability, and the coefficient of $W G S$ is significantly larger in absolute value in the flexible exchange rate regime: the estimated elasticities of profitability to $W G S$ are -.03 and -.48 in a peg and in a flex, respectively, and are statistically different from each other at the $1 \%$ level. The coefficient of $W G S$ in a flex is quantitatively significant: when $W G S$ increases by one average standard deviation, profitability in the flexible exchange rate regime falls by 20 percent (or 286 percent of its average standard deviation). Also, the effect on profitability works mostly through the real product wage, because as shown in Table 1 the effect of fiscal policy on the labor-output ratio is limited. ${ }^{34}$

The point estimates of the effects of $L T A X$ are also consistently negative, and much larger in absolute value in the peg than in a flex: -.22 against -.09, and significant only in the first case. An F-test on the difference between between the two coefficient gives a p-value of .15.

Our model predicts that, with sticky prices, the regime effect in profitability arises from the effects of fiscal variables on the nominal exchange rate.

\footnotetext{
${ }^{34}$ The insignificant effects on $L / Y$ suggest that increasing returns or labor hoarding are not too important.
} 
Column 3 of Table 2 displays a regression of the nominal effective exchange rate $E R$ on our fiscal variables..$^{35}$ In a flexible exchange rate regime, an increase in $W G S$ does induce a considerable and statistically significant appreciation of the nominal effective exchange rate; the F-test of the difference of the coefficient of $W G S$ in the two regimes has a p-value of .03. Also consistent with our theory, an increase in $L T A X$ does induce a depreciation in a flexible exchange rate regime; however, the coefficient is small, and insignificant. Since the exchange rate effect of $L T A X$ depends on its impact on the level of output, this small implied output effect helps to explain the weaker effects of $L T A X$ than of $W G S$ in the profitability regressions. In turn, a small output effect can be rationalized by a low degree of pass-through from wages to prices ( $\phi$ and $\lambda$ small) and/or a small response of wages to tax changes. ${ }^{36}$

The key message of Table 2 is that wage government spending has a powerful negative effect on profitability, and a much stronger one in a flexible exchange rate regime because of the appreciation it induces, with p-values from a T-test on the difference far below .05. Labor taxation also has a negative effect on profitability via its positive impact on the real wage, and stronger in a fixed exchange rate regime. However, the p-values are marginally outside conventional significance levels. Moreover, the estimated effects of labor taxation are smaller than those of wage government spending: the coefficient of $L T A X$ in a peg is about half that of $W G S$ in a flex.

We have found evidence in Tables 1 and 2 of weak output and employment effects in the traded sector but a larger impact on real product wages and profitability. Moreover, there is evidence of difference across exchange rate regimes in the transmission of $W G S$ to the "price" variables. As stated earlier, our model predicts no regime effect in quantities but a regime effect in prices. The larger impact on prices than on quantities (in both regimes) can be rationalised by a high degree of nominal rigidity and/or a reluctance by firms to pass on cost increases to final customers.

Finally, in the web appendix, we show that these results are generally robust along several dimensions: rescaling the fiscal variables; focusing on

\footnotetext{
${ }^{35}$ We construct the nominal effective exchange rate for country $i$ as a trade-weighted average of the nominal exchange rates with the other countries in the sample, with the weight of country $j$ equal to the share of exports from country $i$ to country $j$ in total exports from country $i$. An increase in the nominal effective exchange rate represents a depreciation.

${ }^{36}$ In the model, we assumed labor supply depended on the after-tax real wage.
} 
the unanticipated component of fiscal policy; adding extra countries; and differentiating between small and large countries.

\section{Conclusions}

In this paper, we have emphasized the short-run macroeconomic effects of different types of fiscal policy. We distinguished between two transmission mechanisms: a cost channel and an exchange rate channel. For both effects to be operative, wages and prices must display partial flexibility with respect to fiscal policy. If wages and prices are fully flexible, the exchange rate channel is inoperative; if wages and prices are fully rigid, there are no short-run cost effects from fiscal policy.

On a panel of OECD countries from 1964 to 1993, we found that increases in wage government spending raise the real product wage and depress profitability in the traded sector. These results indicate the operation of a significant cost channel in the transmission of fiscal policy. Moreover, the positive impact on the real product wage and the negative impact on profitability are significantly larger under a flexible exchange rate regime, consistent with the presence of an exchange rate channel. That both the cost and the exchange rate channels are active suggests that partial flexibility in wages and prices is a good description of the nature of adjustment to fiscal shocks in the economies we study in this paper. That fiscal policy has a smaller impact on quantities than on the real product wage and profitability suggests that the pass-through of higher costs into prices is limited, either because prices are largely sticky or it is not optimal for firms to maintain a constant markup in the face of cost increases.

The weaker results for taxation may be partly attributable to measurement problems. However, since tax policy only influences the exchange rate via its impact on the level of private sector output, the small quantity responses we observe also imply small effects on the exchange rate and small differences across exchange rate regimes. Understanding better the impact of tax policy on exchange rates represents a challenge for future research. In line with our theoretical prior, non-wage government spending on goods and services has only minor effects on the traded sector.

Thus, this paper has provided evidence that the composition of a shift in fiscal policy is important in determining its impact on the traded sector. This is relevant in the design of fiscal adjustment programs. A fiscal reform 
that takes the form of a reduction in wage government spending will crowd in an expansion in traded output and employment and improve the level of profitability. A reform that consists of an increase in labor taxation will have the opposite effect on the traded sector.

A second message is that the choice of the exchange rate regime matters for the impact of fiscal reforms on key macroeconomic variables. For instance, under flexible exchange rates, a reduction in wage government spending doubly improves profitability in the traded sector: not only do labor costs fall but firms in the traded sector also benefit from the induced exchange rate depreciation.

Our study has focused on the impact of fiscal policy on the tradable sector of the economy. The tradable sector is especially interesting, since we have shown that domestic fiscal policy can importantly influence an economy's international competitiveness, by altering unit labor costs and profitability. In future work, it would be interesting to also examine the impact of fiscal policy on the private nontradable sector, under alternative exchange rate regimes, in order to gain a sense of its overall impact on aggregate macroeconomic indicators. The relative importance of the two sectors will obviously vary in line with country size, with our results for the tradable sector being most critical for the smaller, more open economies. 


\section{Technical Appendix}

In this section, we prove that an expansion in $L_{g}$ causes GDP to rise and hence the exchange rate to appreciate.

From equation (6), the impact of an increase in $L_{g}$ on GDP is given by

$$
\begin{gathered}
\frac{\partial Q}{\partial L_{g}}=\frac{w}{S}+\frac{\partial(W / S)}{\partial L_{g}} L_{g}+ \\
\frac{\partial(W / S)}{\partial L_{g}}\left[H_{1} L+P^{*} H_{1} G_{1}\right]
\end{gathered}
$$

Since $G_{1}<0$, this expression has an ambiguous sign. Manipulation delivers the following condition for the derivative to be positive

$$
\epsilon_{W / S, L_{g}}<\frac{L_{g}}{\epsilon_{P^{*}, W / S} \kappa_{0} L\left(\epsilon_{Y, P^{*}}-1\right)-L_{g}}
$$

where $\kappa_{0}$ is the markup in the full flexibility case, $\epsilon_{W / S, L_{g}}$ is the elasticity of the real wage with respect to government employment, $\epsilon_{P^{*}, W / S}$ is the elasticity of the price to the real wage, and $\epsilon_{Y, P^{*}}$ is the price elasticity of output demand (signed to be positive).

From equations (2) and (3) above, we can write the implicit function

$$
F\left((1-\tau) \frac{w}{S}\right)=G\left[H\left(\frac{w}{S}\right)\right]+L_{g}
$$

which gives the partial derivative

$$
\frac{\partial w / S}{\partial L_{g}}=\frac{1}{(1-\tau) F_{1}-G_{1} H_{1}}
$$

Since $F_{1}, H_{1}>0$ and $G_{1}<0$, we know the impact of an increase in $L_{g}$ will be positive on $W / S$. Some extra steps deliver the elasticity

$$
\epsilon_{W / S, L_{g}}=\frac{L_{g}}{L}\left[\frac{1}{\epsilon_{L_{s}}+\epsilon_{L_{d}}}\right]
$$

Hence, the elasticity of the real wage with respect to $L_{g}$ depends positively on the relative size of the government sector $L_{g} / L$ and negatively on the elasticities of labor supply and labor demand. The elasticity of labor demand 
in our setup is the product of (i) the price elasticity of output demand, $\epsilon_{Y, P^{*}}$, and (ii) the elasticity of price with respect to the real wage, $\epsilon_{P^{*}, W / S}$.

In the monopolistic competition case, the latter is 1 and the former is $\theta$. Thus, the elasticity of the real wage to government employment in this case is

$$
\epsilon_{W / S, L_{g}}=\frac{L_{g}}{L}\left[\frac{1}{\epsilon_{L_{s}}+\theta}\right]
$$

Also, under monopolistic competition condition (.2) reduces to

$$
\epsilon_{W / S, L_{g}}<\frac{L_{g}}{\theta L-L_{g}}
$$

Using (.6), it is easy to show that (.7) is always satisfied in the monopolistic competition case, because it reduces to the condition $(\theta-\lambda)<\left(\theta+\epsilon_{L s}\right)$ where $\lambda=L_{g} / L$. A fortiori, the condition is satisfied under market structures in which wage increases are not fully passed through to prices, since the rising real wage does not prompt as a big fall in output and labor demand in the traded sector. 


\section{References}

Alesina, A. and S. Ardagna (1998): "Tales of Fiscal Adjustments", Economic Policy, XXVII.

Alesina, A., Ardagna, S., Schiantarelli, F., and R. Perotti (1999): "Fiscal Policy, Profits, and Investment", mimeo, Harvard University; forthcoming, American Economic Review.

Alesina, A. and R. Perotti (1995): "Fiscal Expansions and Fiscal Adjustments in OECD countries", Economic Policy, XXI, 205-48.

Alesina, A. and R. Perotti (1997a): "Fiscal Adjustments in OECD Countries: Composition and Macroeconomic Effects", IMF Staff Papers, XLIV, 210-48.

Alesina, A. and R. Perotti (1997b): "The Welfare State and Competitiveness", American Economic Review, LXXXVII, 921-39.

Alogoskoufis, G. (1992), "Fiscal Policies, Devaluations and Exchange Rate Regimes: The Stabilization Programmes of Ireland and Greece, Economic and Social Review, 23, 225-246.

Ball, L. and D. Romer (1990), "Real Rigidities and the Non-Neutrality of Money," Review of Economic Studies, 57, 183-203.

Bertola, G. and A. Drazen (1993), "Trigger Points and Budget Cuts: Explaining the Effects of Fiscal Austerity," American Economic Review, March, 83(1), 11-26.

Blanchard, O. (1993): "Suggestions for a New Set of Fiscal Indicators" (1993), in The Political Economy of Government Debt, Harrie A. A. Vernon and Frans A. A. M. Van Winden, eds. (North-Holland, Amsterdam).

Blanchard, O. and P. Muet (1993), "Competitiveness Through Disinflation: An Assessment of the French Macroeconomic Strategy," Economic Policy 8 (16), 11-56.

Bruno, M. and J. Sachs (1985), The Economics of Worldwide Stagflation, Oxford: Basil Blackwell. 
De Gregorio, J., A. Giovannini and H. Wolf (1994), "International Evidence on Tradables and Nontradables Inflation," European Economic Review, $1225-45$.

Dornbusch, R. (1987), "Exchange Rates and Prices," American Economic Review 77, 93-106.

Engel, C. (1999), "Accounting for US Real Exchange Rate Changes," Journal of Political Economy, forthcoming.

European Commission (1994): European Economy, No. 56.

Flood, R. and A. Rose (1995), "Fixing Exchange Rates: A Virtual Quest for Fundamentals," Journal of Monetary Economics 36, 3-37.

Frenkel, J. Razin A., and C.Yuen (1996), Fiscal Policies and Growth in the World Economy, Cambridge, MA: MIT Press.

Froot, K. and K. Rogoff (1991), "Government Spending and the Real Exchange Rate," unpublished paper, Harvard Business School.

Giavazzi, F. and M. Pagano (1990), "Can Severe Fiscal Adjustments be Expansionary?", in: O. Blanchard and S. Fischer, eds, NBER Macroeconomics Annual, Cambridge, MA: MIT Press, 75-110.

Giavazzi, F. and M. Pagano (1996): "Non-Keynesian Effects of Fiscal Policy Changes: International Evidence and the Swedish Experience", Swedish Economic Policy Review, III, 67-103.

Giavazzi, F., Jappelli, T., and M. Pagano (1998): "Searching for NonKeynesian Effects of Fiscal Policy", mimeo, IGIER.

Giorno, C., Richardson, P., Roseveare, D., and P. van der Noord (1995): "Estimating Potential Output, Output Gaps, and Structural Budget Balances", Organization for Economic Co-Operation and Development, Paris.

Helpman, E. (1976), "Macroeconomic Policy in a Model of International Trade with a Wage Restriction," International Economic Review, 17, 262-277. 
Helpman, E. (1977), "Nontraded Goods and Macroeconomic Policy under a Fixed Exchange Rate," Quarterly Journal of Economics, 91, 469-480.

Im, K. S., M. H. Pesaran, and Y. Shin (1995): "Testing for Unit Roots in heterogeneous Panels", mimeo, Cambridge University.

Krugman, P. and E. Helpman (1989), Trade Policy and Market Structure, MIT Press.

Kouri, P. (1982), "Profitability and Growth," Scandinavian Journal of Economics 84, 317-339.

Mendoza, E. and L. Tesar (1998), "The International Ramifications of Tax Reforms: Supply-side Economics in a Global Economy," American Economic Review, 88, 226-245.

Perotti, R. (1999), "Fiscal Policy in Good Times and Bad", Quarterly Journal of Economics, November.

Phelps, E. (1994), Structural Slumps, Cambridge, MA: Harvard University Press.

Sachs, J. (1979), "Wages, Profits and Macroeconomic Adjustment: A Comparative Study," Brookings Papers on Economic Activity 2, 269-319.

Sargent, T. (1987), Dynamic Macroeconomic Theory, Harvard University Press.

Stockman, A. and L. Ohanian (1993), "Short-Run Independence of Monetary Policy under Pegged Exchange Rates and Effects of Money on Exchange Rates and Interest Rates," NBER Working Paper No. $451 \%$. 
Table 1: Quantities

\begin{tabular}{|c|c|c|c|}
\hline dep. var. & $\begin{array}{c}\mathrm{Y} \\
(1)\end{array}$ & $\begin{array}{c}\mathrm{L} \\
(2)\end{array}$ & $\begin{array}{c}\mathrm{L} / \mathrm{Y} \\
(3)\end{array}$ \\
\hline 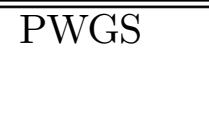 & $\begin{array}{l}-0.02 \\
(0.15)\end{array}$ & $\begin{array}{l}-0.02 \\
(0.22)\end{array}$ & $\begin{array}{c}-0.00 \\
(0.02)\end{array}$ \\
\hline FWGS & $\begin{array}{c}-0.15 \\
(1.36)\end{array}$ & $\begin{array}{l}-0.03 \\
(0.31)\end{array}$ & $\begin{array}{c}0.12 \\
(1.28)\end{array}$ \\
\hline PNWGS & $\begin{array}{c}0.06 \\
(1.19)\end{array}$ & $\begin{array}{c}0.08 \\
(2.05)\end{array}$ & $\begin{array}{c}0.02 \\
(0.50)\end{array}$ \\
\hline FNWGS & $\begin{array}{l}-0.01 \\
(0.12)\end{array}$ & $\begin{array}{c}0.02 \\
(0.38)\end{array}$ & $\begin{array}{c}0.03 \\
(0.49)\end{array}$ \\
\hline PLTAX & $\begin{array}{c}-0.08 \\
(1.27)\end{array}$ & $\begin{array}{c}0.02 \\
(0.45)\end{array}$ & $\begin{array}{c}0.10 \\
(1.87)\end{array}$ \\
\hline FLTAX & $\begin{array}{l}-0.13 \\
(2.25)\end{array}$ & $\begin{array}{c}-0.04 \\
(0.77)\end{array}$ & $\begin{array}{c}0.09 \\
(1.89)\end{array}$ \\
\hline PWY & $\begin{array}{c}0.43 \\
(0.68)\end{array}$ & $\begin{array}{c}0.87 \\
(1.75)\end{array}$ & $\begin{array}{c}0.45 \\
(0.82)\end{array}$ \\
\hline FWY & $\begin{array}{c}1.32 \\
(2.66)\end{array}$ & $\begin{array}{c}0.64 \\
(1.64)\end{array}$ & $\begin{array}{c}-0.67 \\
(1.57)\end{array}$ \\
\hline $\mathrm{R} 2$ & 0.58 & 0.42 & 0.44 \\
\hline Nobs & 408 & 408 & 408 \\
\hline DoF & 319 & 319 & 319 \\
\hline p(WGS) & 0.38 & 0.94 & 0.35 \\
\hline $\mathrm{p}$ (NWGS) & 0.41 & 0.34 & 0.94 \\
\hline $\mathrm{p}(\mathrm{LTAX})$ & 0.54 & 0.39 & 0.95 \\
\hline
\end{tabular}

P: dummy variable for pegged exchange rate regime; F: dummy variable for flexible exchange rate regime. All regressions also include dummy variable for realignments and for the 1974-75 oil shock, all also interacted with the fiscal policy variables. $\mathrm{p}(\mathrm{X})$ : $\mathrm{p}$-value from $\mathrm{F}$ test that coefficient on PX and FX are the same. 
Table 2: Prices

\begin{tabular}{|c|c|c|c|}
\hline dep. var. & $\begin{array}{l}\omega \\
(1)\end{array}$ & $\begin{array}{l}\pi \\
(2)\end{array}$ & $\begin{array}{l}\text { ER } \\
(3)\end{array}$ \\
\hline$\overline{P W G S}$ & $\begin{array}{c}0.03 \\
(0.28)\end{array}$ & $\begin{array}{l}-0.03 \\
(0.25)\end{array}$ & $\begin{array}{c}-0.02 \\
(0.10)\end{array}$ \\
\hline FWGS & $\begin{array}{c}0.36 \\
(3.12)\end{array}$ & $\begin{array}{c}-0.48 \\
(3.92)\end{array}$ & $\begin{array}{c}-0.58 \\
(3.12)\end{array}$ \\
\hline PNWGS & $\begin{array}{c}0.03 \\
(0.54)\end{array}$ & $\begin{array}{l}-0.05 \\
(0.89)\end{array}$ & $\begin{array}{c}0.05 \\
(0.67)\end{array}$ \\
\hline FNWGS & $\begin{array}{c}0.01 \\
(0.19)\end{array}$ & $\begin{array}{c}-0.04 \\
(0.56)\end{array}$ & $\begin{array}{c}0.01 \\
(0.10)\end{array}$ \\
\hline PLTAX & $\begin{array}{c}0.12 \\
(1.93)\end{array}$ & $\begin{array}{l}-0.22 \\
(3.26)\end{array}$ & $\begin{array}{c}-0.04 \\
(0.43)\end{array}$ \\
\hline FLTAX & $\begin{array}{l}-0.01 \\
(0.15)\end{array}$ & $\begin{array}{c}-0.09 \\
(1.33)\end{array}$ & $\begin{array}{c}0.08 \\
(0.81)\end{array}$ \\
\hline PWY & $\begin{array}{l}-0.31 \\
(0.47)\end{array}$ & $\begin{array}{c}-0.14 \\
(0.19)\end{array}$ & $\begin{array}{c}-0.46 \\
(0.43)\end{array}$ \\
\hline FWY & $\begin{array}{c}0.19 \\
(0.37)\end{array}$ & $\begin{array}{c}0.48 \\
(0.87)\end{array}$ & $\begin{array}{c}-0.56 \\
(0.67)\end{array}$ \\
\hline $\mathrm{R} 2$ & 0.36 & 0.29 & 0.22 \\
\hline Nobs & 408 & 408 & 408 \\
\hline DoF & 319 & 319 & 319 \\
\hline p(WGS) & 0.04 & 0.01 & 0.03 \\
\hline $\mathrm{p}$ (NWGS) & 0.86 & 0.91 & 0.74 \\
\hline $\mathrm{p}(\mathrm{LTAX})$ & 0.13 & 0.15 & 0.39 \\
\hline
\end{tabular}

See Table 1. 